\title{
Construction and validation of checklist for disinfecting ambulances to transport Covid-19 patients
}

\author{
Construção e validação de checklist para desinfecção de \\ ambulâncias para transporte de pacientes Covid-19 \\ Construcción y validación de checklist para la desinfección de \\ ambulancias para el transporte de pacientes Covid-19 \\ Ana Carla Silva Alexandre ${ }^{a}$ \\ Nelson Miguel Galindo Neto ${ }^{a}$ \\ Maria Aparecida de Souza Silva ${ }^{a}$ \\ Dária Catarina Silva Santos ${ }^{a}$ \\ Josicleide Montenegro da Silva Guedes Alcoforado ${ }^{a}$ \\ Daniela Bezerra de Melo ${ }^{a}$
}

How to cite this article: Alexandre ACS, Galindo Neto NM, Souza Silva MA, Silva Santos DC, Alcoforado JMSG, Melo DB. Construction and validation of checklist for disinfecting ambulances to transport Covid-19 patients. Rev Gaúcha Enferm. 2021;42(spe):e20200312. doi: https://doi.org/10.1590/19831447.2021.20200312
Instituto Federal de Educação Ciência e Tecnologia de Pernambuco (IFPE), Campus Pesqueira, Departamento de Enfermagem. Recife, Pernambuco, Brasil.

\section{ABSTRACT}

Objective: To build and validate a checklist for disinfecting ambulances transporting patients with Covid-19.

Method: Methodological study composed by the construction of a checklist and validation by 42 professionals, of which 35 professionals had expertise in patient transport/transfer and seven in hospital infection control. The item with a minimum agreement of $80 \%$ was considered valid, based on the Content Validation Index and binomial test.

Results: The checklist had the steps performed for terminal disinfection of ambulances. It had 54 items, which included the personal protective equipment and used materials, disinfection of the driver's cabin, equipment, and the patient care cabin. The minimum agreement obtained was $85 \%$ and the mean of the Content Validation Index was 0.96.

Conclusion: The checklist was considered valid in terms of content and can be used to disinfect ambulances transporting patients with Covid-19.

Keywords: Coronavirus infections. Disinfection. Validation study. Ambulances.

\section{RESUMO}

Objetivo: Construir e validar checklist para desinfecção de ambulâncias que transportam pacientes com Covid-19.

Método: Estudo metodológico composto pela construção de checklist e validação por 42 profissionais, dos quais 35 profissionais possuíam expertise em transporte/transferência de pacientes e sete em controle de infecção hospitalar. Foi considerado válido o item com concordância mínima de 80\%, a partir do Índice de Validação de Conteúdo e teste binomial.

Resultados: 0 checklist possuiu as etapas que devem ser realizadas para desinfecção terminal das ambulâncias. Possuiu 54 itens, que contemplaram os equipamentos de proteção individual e materiais utilizados, desinfecção da cabine do condutor, dos equipamentos e da cabine de atendimento ao paciente. A concordância mínima obtida foi de 85\% e a média do Índice de Validação de Conteúdo foi de 0,96 .

Conclusão: 0 checklist foi considerado válido quanto ao conteúdo e pode ser utilizado para desinfecção das ambulâncias que transportam pacientes com Covid-19.

Palavras-chave: Infecções por coronavírus. Desinfecção. Estudo de validação. Ambulâncias.

\section{RESUMEN}

Objetivo: Construir y validar checklist para desinfectar ambulancias que transportan pacientes con Covid-19.

Método: Un estudio metodológico compuesto por la construcción de un checklist y validación por 42 profesionales, de los cuales 35 profesionales tenían experiencia en transporte/transferencia de pacientes y siete en control de infecciones hospitalarias. El ítem con un acuerdo mínimo del 80\% se consideró válido, según el índice de validación de contenido y la prueba binomial.

Resultados: El checklist tenía los pasos a seguir para la desinfección terminal de ambulancias. Tenía 54 artículos, que incluían el equipo de protección individual y los materiales utilizados, la desinfección de la cabina del conductor, el equipo y la cabina de atención al paciente. El acuerdo mínimo obtenido fue del 85\% y el promedio del Índice de Validación de Contenido fue de 0,96.

Conclusión: El checklist se consideró válido en términos de contenido y puede usarse para desinfectar ambulancias que transportan pacientes con Covid-19.

Palabras clave: Infecciones por coronavirus. Desinfección. Estudio de validación. Ambulancias. 


\section{INTRODUCTION}

The Unified Health System (Sistema Único de Saúde SUS), based on decentralization and regionalization, has highly complex centers, to which patients are transferred, in search of resolving health demands ${ }^{(1)}$. In this context, inter-hospital and inter-municipal transfers are carried out by the Mobile Emergency Care Service (Serviço de Atendimento Móvel de Urgência - SAMU) or by ambulances at the municipal and/or hospital level ${ }^{(2)}$. Such ambulances, after making the transfers, need to undergo terminal disinfection, especially if the transferred patient is affected by infectious disease or respiratory transmission.

Among the viral diseases of respiratory transmission that require transfer of patients and, therefore, subsequent disinfection of the ambulance, the Coronavirus Disease 2019 (Covid-19) stands out. It was considered by the World Health Organization (WHO) as a pandemic, has high transmissibility and presents itself as a public health emergency due to its high population involvement and mortality ${ }^{(3)}$.

In view of the inevitable need to transfer confirmed or suspected cases of Covid-19, and to address Evidence-Based Practice, it is noteworthy the relevance of scientific investment that contributes to the safety of the health worker who performs the transfer and the patient that is transferred. In Brazil, $3.8 \%$ to $20 \%$ of the infected population is composed by health professionals ${ }^{(4)}$ in a Chinese study, 54 professionals from the medical team were infected and hospitalized, 3.7\% working in the emergency service ${ }^{(5)}$. In addition, a study in the United Kingdom tested 1,533 health workers with symptoms suggestive of Covid-19, of which $18 \%$ were positive(6).

Thus, in view of the impact on the workforce involved in the care of affected patients, possible errors in the process of disinfecting ambulances that transfer Covid-19 cases can be reduced by using checklists, as measures to verify the steps to be taken. In health, checklists are used universally, they are characterized as a cognitive strategy that ensures adequate preparation through the checking of steps for a given procedure. They are associated with greater safety, as they provide a reduction in accidents, failures or adverse events ${ }^{(7-8)}$, in addition to reducing errors and improving the quality of care ${ }^{(9)}$.

Thus, although it is considered pertinent to use a checklist for disinfecting ambulances that transfer patients affected by Covid-19, it is pointed out the relevance of this being the result of a scientific process of construction and validation.

In view of the above, the question that guided the present study was: is the checklist on disinfection of patient transport vehicles with Covid-19 confirmation/suspicion valid in terms of content, language, and layout, as assessed by experts?
Due to the lack in the literature of specific checklist for the studied context, the present study aimed to build and validate a checklist for disinfecting ambulances transporting patients with Covid-19 confirmation or suspicion.

\section{METHOD}

Methodological study composed by the construction and validation of a checklist on the disinfection of ambulances for transfer/transport of patients with confirmation or suspicion of Covid-19, carried out in a virtual environment from May to June 2020, using electronic contact with professionals from five regions of Brazil.

The study population consisted of health professionals with expertise in patient transport/transfer or in Hospital Infection Control Committee (HICC). When considering two categories of professionals eligible for the study, the inclusion criterion adopted was having experience (assistance or teaching/research) in transport/transfer or HICC. The exclusion criterion was sending the data collection instrument with incomplete completion.

The sample was calculated using the formula $n=-$ $\mathrm{Za}^{2} . P(1-\mathrm{P}) / \mathrm{e}^{2(10)}$ using the following parameters: confidence level $(\mathrm{Za})=95 \%$; proportion of judges' agreement $(\mathrm{P})=80 \%$; admitted difference $(e)=15 \%$. Thus, a value of 28 participants was obtained.

The participants were selected by "snowball" sampling, in which professionals virtually approached were asked to indicate others with an eligible profile. Thus, there was feedback from 42 professionals and, when considering the relevance of the suggested adjustments and their expertise on the subject assessed, all were included in the sample.

Twenty-four variables were investigated, of which 13 were related to the characterization of the participants: age, gender, state of residence, training, higher degree, area of expertise, current professional practice, previous professional practice, length of experience in years, area of specialization, master's and doctorate, experience in teaching courses and/ or discipline related to the disinfection of ambulances and the cleaning and disinfection of surfaces, participation as a student in course and/or training on disinfection of ambulances and on cleaning and disinfection of surfaces. The remaining 11 variables consisted by the items for which the participants' agreement was assessed, of which four were related to content; three, to language; and three, to the layout.

The instrument, adapted from another validation study ${ }^{(11)}$, was composed by 13 questions related to professional characterization and 11 focused on the content, language and layout of the checklist. The response options for recording the raters' agreement were on a Likert-type 
scale, with the following options to be checked: agree, strongly agree, neither agree nor disagree, disagree and strongly disagree. In addition, the instrument had space for recording opinions or suggestions. It should be noted that the checklist was subdivided into five parts, which were evaluated separately, so that, for each part of the checklist, the instrument, with the 11 questions and space for suggestions, was replicated.

The instrument used was organized in a Survey format using the Google Forms tool divided into seven sections: the first had the Free and Informed Consent Term (ICF), in which the professional could indicate their agreement to participate in the study; the second was composed by 13 questions about the characterization of professionals; and each of the remaining sections (third to seventh), contemplated one of the five parts of the checklist and the questions to be filled, for each part.

For participants recruitment, the link to access the electronic form, along with an invitation text, was sent to 15 nursing professors from public institutions in the states of Pernambuco, Ceará and Piauí, Paraíba, Mato Grosso, São Paulo, Rio de Janeiro and Minas Gerais, of which the researchers had contact. In addition, there was the sharing of the link and group invitation text of the multiplatform instant messaging application, WhatsApp, composed by professionals from all Brazilian states, in the area of Urgency and Emergency, which includes expertise in transfer/ transport of patients.

It is noteworthy that in the invitation text there was a request for sharing and indication of other professionals with a eligible profile to participate in the study. After three days of submissions, responses were received from 42 professionals.

Data analysis was performed using software $R$, version 3.1.1. The Content Validation Index (CVI) was used, the calculation of which was performed, per item, by summing the answers "I agree" and "I totally agree", with subsequent division of this sum, by the total value of the answers. The binomial test was used to verify whether the agreement was statistically equal to or greater than $80 \%$, which consisted of the value used for the item to be considered valid ${ }^{(12)}$.

The study complied with Resolution 466/12 with approval, under statement number 4,002,976, by the Research Ethics Committee of the Educational Autarchy of Belo Jardim - PE, Brazil.

\section{DESULTS}

The final version was entitled "Checklist for disinfection of ambulances", consisting of a page, with a header for filling in the date, time, and name of the professional, followed by
54 items referring to the steps that must be performed for terminal disinfection of ambulances.

The items to be checked were subdivided into five sections that included: personal protective equipment and materials used; disinfection of driver's cabin; material removal and disinfection; cleaning/washing and disinfecting the patient care cabin (Figure 1).

From the 42 professionals who validated the checklist, seven (16.67\%) had experience in HICC/biosafety and 35 (83.33\%) in the area of Urgency and emergency/Patient transfer, 24 (57.1\%) had experience in teaching, 35 (83.4\%) in assistance, eight (19\%) in research and seven (16.7\%) in management. It is noteworthy that the sum of the percentages cited exceeds the total of 100\%, since the judges had more than one area of experience.

Regarding the highest degree, 21 (50\%) were specialists, nine (21.4\%) masters, nine (21.4\%) doctors and three (7.1\%), graduates. It was observed that 21 (50\%) had already received training on disinfection of ambulance, and 35 (83.3\%) on surface disinfection. Regarding teaching on the subject, 18 (42.9\%) had taught a course and/or discipline, which dealt with disinfection of ambulances and 28 (66.7\%), course and/or discipline which dealt with cleaning and disinfecting surfaces.

From the five sections evaluated in the checklist, "PPE and materials used" obtained the agreement of all the judges about having an understandable presentation, having a clear and objective language, font size that favors reading and having the items in an organized manner. The section "disinfection of driver's cabin", in addition to obtaining unanimity of agreement on the same items mentioned, also obtained unanimity about the pertinence, the fact of helping the professional who performs the disinfection and having a language compatible with the target audience (Table 1).

In the section "material removal and disinfection" the lowest proportion of agreement was 92\%; in "cleaning and washing the patient care unit", it was 85\%; and in the "disinfecting patient care unit" section, it was 95\%, as detailed in Table 2.

The evaluation of the 11 items in each of the five sections totaled 55 items evaluated, of which the lowest proportion of agreement was $85 \%$, obtained in two (3.6\%) of them, and the highest was of unanimous agreement, in 21 (38.2\%). Thus, the overall CVI was 0.96 and, for a value greater than $80 \%$ and the non-significance of the binomial test in all items, the checklist was considered valid in terms of content by the judges.

After the judges'assessment, 23 adjustment suggestions presented in Figure 2, for the five checklist sections, were obtained and properly performed. 


\section{CHECLIST FOR DISINFECTION OF AMBULANCES}

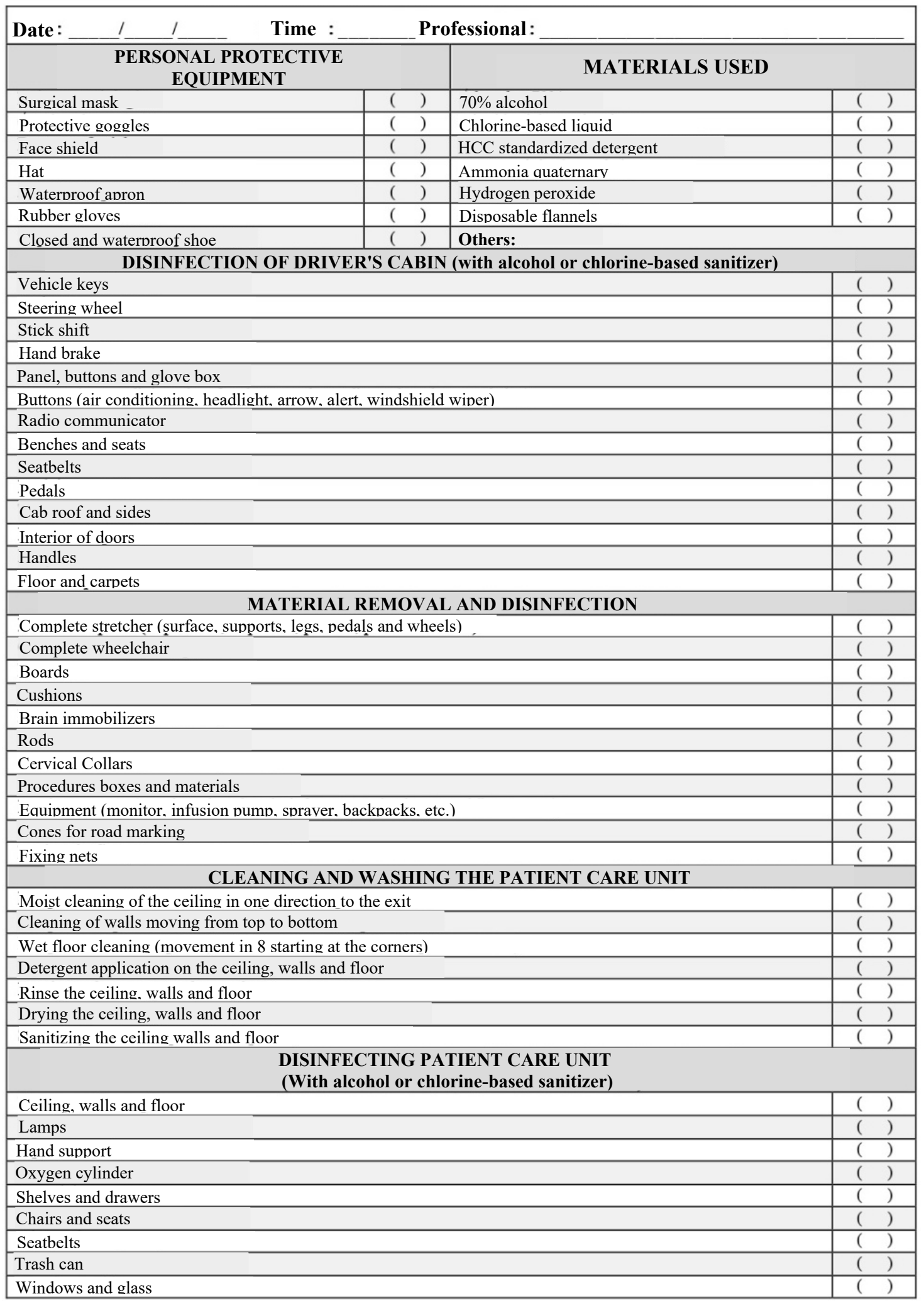

Figure 1 - Checklist on disinfection of ambulances transporting patients with confirmation or suspicion of Covid-19. Pesqueira, PE, Brazil, 2020 Source: Authors, 2020. 
Table 1 - Judges' agreement in the sections "PPE and materials used" and "disinfection of driver's cabin", regarding content, language, and layout. Pesqueira, PE, Brazil, 2020

\begin{tabular}{|c|c|c|c|c|}
\hline \multirow{2}{*}{ Items } & \multicolumn{2}{|c|}{$\mathrm{PPE}^{\ddagger}$ and materials used } & \multicolumn{2}{|c|}{ Disinfection of driver's cabin } \\
\hline & $\mathbf{C V} \mathbf{I}^{*}$ & $\mathbf{p}^{\dagger}$ & $\mathbf{C V} \mathbf{I}^{*}$ & $\mathbf{p}^{\dagger}$ \\
\hline \multicolumn{5}{|l|}{ Content } \\
\hline 1 - It is pertinent for the checklist & 0.92 & 0.961 & 1 & 1 \\
\hline 2- Help those who perform disinfection & 0.97 & 0.998 & 1 & 1 \\
\hline 3- It is scientifically correct & 0.85 & 0.617 & 0.90 & 0.893 \\
\hline 4- Presented in an understandable manner & 1 & 1 & 1 & 1 \\
\hline \multicolumn{5}{|l|}{ Language } \\
\hline 5- Compatible with the target audience & 0.97 & 0.998 & 1 & 1 \\
\hline 6- The sentences' formulation is attractive & 0.92 & 0.961 & 0.95 & 0.990 \\
\hline 7- It is clear and objective & 1 & 1 & 1 & 1 \\
\hline \multicolumn{5}{|l|}{ Layout } \\
\hline 8- Font size favors reading & 1 & 1 & 0.97 & 0.998 \\
\hline 9- Colors make reading possible & 0.90 & 0.893 & 0.88 & 0.617 \\
\hline 10-The items disposition is organized & 1 & 1 & 1 & 1 \\
\hline 11- Number of pages is consistent & 0.95 & 0.990 & 0.97 & 0.998 \\
\hline
\end{tabular}

Source: Research data, 2020

Legend: *Item-level Content Validity Index; " tbinomial test;

\section{DISCUSSION}

The scenario of possible viral spread within the vehicle puts the professional team at risk of contamination. A study carried out in the State of Maranhão corroborates this, stating that $81.3 \%$ of SAMU professionals are exposed to biological occupational risks, related to contact with infectious diseases ${ }^{(13)}$.

This contact can occur through surfaces contaminated by SARS-CoV-2, which is prone to contamination via aerosols or sprays. In a North American experiment ${ }^{(14)}$, the virus was more stable in plastic and stainless steel (72 hours), when compared to copper (four hours) and cardboard (24 hours).
In this sense, such fact requires the use of appropriate Personal Protective Equipment (PPE), in addition to decontamination of the ambulance, as recommended by the World Health Organization $(\mathrm{WHO})^{(15-16)}$, since, it is known of the genesis of aerosols in procedures that may be performed in ambulances, such as cardiopulmonary resuscitation, aspiration of secretions in the airways, oxygen therapy and endotracheal intubation, procedures that put at risk the workforce in the transport of Covid-19 patients $s^{(16-17)}$.

Given the important scenario, the checklist had items about the PPE and materials to be used for terminal disinfection of the vehicle, for which the judges'agreement was unanimous. It is highlighted the need and emphasis of the 
Table 2 - Judges' agreement on cleaning and disinfection of materials and mobile unit. Pesqueira, PE, Brazil, 2020

\begin{tabular}{|c|c|c|c|c|c|c|}
\hline \multirow{2}{*}{ Items } & \multicolumn{2}{|c|}{$\begin{array}{l}\text { Material removal and } \\
\text { disinfection }\end{array}$} & \multicolumn{2}{|c|}{$\begin{array}{c}\text { Cleaning and washing } \\
\text { the PCU }{ }^{\ddagger}\end{array}$} & \multicolumn{2}{|c|}{ Disinfecting the PCU } \\
\hline & CVI* & $p^{\dagger}$ & CVI* & $p^{\dagger}$ & CVI* & $p^{\dagger}$ \\
\hline
\end{tabular}

\section{Content}

1- It is pertinent for the checklist

0.92

0.85

0.617

1

2- Help those who

perform disinfection

0.998

0.97

0.998

1

1

3- It is scientifically correct

0.92

0.961

0.95

0.990

0.97

0.998

4- Presented in an

understandable manner

0.998

0.97

0.998

1

1

\section{Language}

5-Compatible with the target audience

0.990

0.92

0.961

0.97

0.998

0.97

0.998

is attractive

0.95

0.990

0.97

0.998

0.95

0.990

Layout

$\begin{array}{lllllll}\text { 8- Font size favors reading } & 0.95 & 0.990 & 0.95 & 0.990 & 0.95 & 0.990 \\ \text { 9- Colors make reading possible } & 0.92 & 0.961 & 0.92 & 0.961 & 0.95 & 0.990\end{array}$

10-The items disposition

is organized

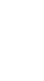

11- Number of pages

is consistent

Source: Research data, 2020.

Legend: *Item-level Content Validity Index; +binomial test; ${ }^{*}$ PCU - patient care unit

aforementioned items, since, for professionals liable to use the checklist, there is a great risk of exposure to the virus, which can be minimized, according to the Centers for Disease Control and Prevention (CDC), from the use of surgical mask, goggles and face shield, hat, waterproof apron, rubber gloves and closed and waterproof shoes ${ }^{(18)}$.

In addition to the necessary PPE, the CDC also recommends isolating the driver's cabin to the patient care area, in order to reduce the risk of spreading viral particles, whether they are droplets, aerosols or sprays ${ }^{(19)}$. Based on this recommendation and the need for didactic division of the steps to be followed for disinfection of ambulances, it is justified the fact that the validated checklist contemplates, separately, the driver's cabin and the patient's treatment unit.

With regard to the disinfection of the driver's cabin, there was an agreement greater than 0.8 in all aspects evaluated. In accordance with the recommendations of the National Health Surveillance Agency (Agência Nacional de Vigilância 


\section{Checklist section}

\section{Adjustment suggestion}

[Replace answer options "( ) Yes ( ) No" with "( )" Apply color to alternating lines

PPE and materials used

Add "hat" to PPE

Replace "mask" with "surgical mask"

Replace "gloves" with "rubber gloves"

Replace "Suitable shoe" with "closed, waterproof shoe"

Add "quaternary ammonia" and "hydrogen peroxide" to materials

Add "Others" with writing space to the materials

Replace "available detergent" with "detergent standardized by HICC"

[Add "benches and seats" and "pedals"

Replace "vehicle panel and glove box" with "Panel, buttons and glove box"

Replace "gear" with "stick shift"

Replace "motorist" with "driver"

Replace "oxygen torpedo" with "oxygen cylinder"

Delete from the title "with alcohol or chlorine-based liquid"

Migrate "oxygen cylinder" to "last section"

Replace "boxes of materials" with "boxes and materials"

Delete "Pulse oximeter"

Replace "monitor" with "Equipment"

Cleaning and washing the patient care unit

Replace "wet sweep" with "wet cleaning"

Replace "wall sweeping" for "wet wall cleaning"

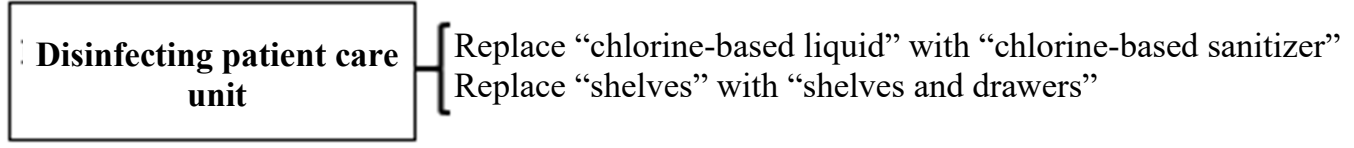

Figure 2 - Judges' suggestions for adjustments to the five-checklist section. Pesqueira, PE, Brazil, 2020

Source: Research data, 2020.

Sanitária - ANVISA), the cleaning and disinfection of the vehicles must occur on all internal surfaces of the vehicle, which includes the driver's cabin, with the use of $70 \%$ alcohol or sanitizer indicated in the services, preferably, through a standard operating procedure aimed at decontaminating activity ${ }^{(19)}$. In this way, the items covered in the checklist, referred to in this section, can contribute to the standardization of the steps to be followed, with a view to contributing to the effectiveness of the activity and reducing the risk of spreading Covid-19.

The material removal and disinfection section was also successful in validating the items. It is necessary that ambulances have inputs, equipment and important items to enable health care during the safe transport of patients, which characterizes them as materials of high handling, as well as which are in contact with the patient. A study carried out in Italy corroborates this fact, by highlighting the need to care for the materials used in transporting Covid-19 patients, which include removing them after transport, for hygiene, replacing emergency bags with others that are clean, carrying out cleaning monitors, mechanical ventilators and other equipment in the vehicle, as well as reprocessing or discarding oxygen inhalation therapy equipment ${ }^{(20)}$.

Other relevant steps, presented in sequence in the content of the checklist, were related to the correct disinfection of surfaces, walls and ceiling. When considering the contact and respiratory transmission of Covid-19, it becomes relevant to disinfect the surfaces of the vehicle/ambulance, since these may constitute fomites, given the fact that the virus remains on them, viable for infection, for days ${ }^{(18)}$.

It is noteworthy that the roof must be subjected to wet cleaning, unidirectional, intended for the vehicle door; the walls must be subjected to wet cleaning, carried out from unidirectional movements from the ceiling to the floor, while the cleaning of the floor must occur in movements in eight, starting from the corners. Subsequently, the ceiling, 
walls and floor must go through the process of applying the detergent, rinsing and drying and to the walls and floor sanitization should be added ${ }^{(18-19,21)}$.

It is necessary to reiterate that there is a variability in the clinical picture of the disease, which runs through stages from mild to moderate, including "flu syndrome"; mild without the need for oxygen inhalation therapy or hospitalization (80\% of symptomatic cases); and/or severe (about 15\% of cases) in which are included patients with evolution to pneumonia, hypoxemia and high risk of respiratory failure due to their critical condition ${ }^{(22)}$.

These patients are those who will inevitably need mechanical ventilation and adequate transportation in ambulances with advanced life support until they arrive at the reference hospitals for their hospitalization ${ }^{(22)}$. Thus, the detailed presentation of the steps, in the checklist, can contribute to the execution of all steps and, thus, with the reduction of the probability of illness of professionals by Covid-19, during a work process of such complexity and need at current conjuncture.

\section{a CONCLUSION}

The final version of the checklist on the terminal disinfection of patient transport vehicles with confirmation or suspicion of Covid-19 addressed the correct sequence and the conducts to be performed, for the correct disinfection of the personal protective equipment and materials used; disinfection of the driver's cabin; removal and disinfection of materials; cleaning/washing and disinfecting the patient care cabin.

The content validation had statistically agreement greater than $80 \%$ in all items, referring to content, language, and layout and the global CVI was 0.96 , so that the checklist was considered valid regarding the content.

As a limitation, it is pointed out the fact that the research took place with evaluations of judges working in the Brazilian context, which makes possible that the findings may differ in opinion, agreement and suggestions that would be obtained with professionals from other countries.

Despite this, checklists submitted to the scientific validation process, have greater credibility as to their content and a greater chance of being comprehensible and viable for use. The steps described in the built and validated checklist, if performed correctly, can contribute to reducing the transmission of the new coronavirus to healthcare professionals and patients to be transferred/transported in the same vehicle/ ambulance manned by a suspected or confirmed case of Covid-19.
In addition, the methodological path presented can be replicated in research that aims to build and validate checklists referring to other conducts necessary for the prevention of Covid-19, since there are still bibliographic gaps regarding the development of safe protocols for disinfection of different sites with similar purposes about this illness.

The checklist can contribute to the professionals involved in the disinfection of vehicles and, thus, reduce the chain of transmission and contribute to the safety of professionals in the face of the pandemic by Covid-19. It is highlighted the need for new studies that translate and cross-culturally adapt the checklist to other languages and contexts in other countries. In addition, it is recommended that future studies analyze the effectiveness of using the checklist, in preventing contamination and illness of professionals.

\section{REFERENCES}

1. Hemesath MP, Kovalski AV, Echer IC, Lucena AF, Rosa NG. Effective communication on temporary transfers of inpatient care. Rev Gaucha Enferm. 2019;40(esp):e20180325. doi: https://doi. org/10.1590/1983-1447.2019.20180325

2. Battisti GR, Branco A, Caregnato RCA, De Oliveira MMC. Profile of service and satisfaction of users of the Mobile Emergency Care Service (SAMU). Rev Gaucha Enferm. 2019;40:e20180431. doi: https://doi. org/10.1590/1983-1447.2019.20180431

3. Moren DM, Daszak P, Taubenberger JK. Escaping Pandora's box-another novel Coronavirus. N Engl J Med. 2020;382(14):1293-5. doi: https://doi.org/10.1056/ NEJMp2002106

4. Kowalski LP, Sanabria A, Ridge JA, Ng WT, de Bree R, Rinaldo A, et al. COVID-19 pandemic: effects and evidence-based recommendations for otolaryngology and head and neck surgery practice. Head Neck. 2020;42(6):1259-67. doi: https://doi.org/10.1002/hed.26164

5. Chu J, Yang N, Wei Y, Yue H, Zhang F, Zhao J, et al. Clinical characteristics of 54 medical staff with COVID-19: a retrospective study in a single center in Wuhan, China. J Med Virol. 2020;92(7):807-13. doi: https://doi.org/10.1002/jmv.25793

6. Keeley AJ, Evans C, Colton H, Ankcorn M, Cope A, State A, et al. Roll-out of SARS-COV-2 testing for healthcare workers at a large NHS Foundation Trust in the United Kingdom, March 2020. Euro Surveill. 2020;25(14):2000433. doi: https://doi.org/10.2807/1560-7917.ES.2020.25.14.2000433

7. Purim KSM, Gonçalves CG, Binotto L, Groth AK, Aranha Júnior AA, Chibata $M$, et al. Safety checklist in outpatient surgery teaching. Rev Col Bras Cir. 2019;46(3):e20192197. doi: https://doi.org/10.1590/0100-6991e-20192197

8. Turner JS, Bucca AW, Propst SL, Ellender TJ, Sarmiento EJ, Menard LM, et al. Association of checklist use in endotracheal intubation with clinically important outcomes: a systematic review and meta-analysis. JAMA Netw Open. 2020;3(7):e209278. doi: https://doi.org/10.1001/ jamanetworkopen.2020.9278

9. Wright S, Ucer TC, Croft G. The adaption and implementation of the WHO Surgical Safety Checklist for dental procedures. Br Dent J. 2018;255:727-9. doi: https://doi.org/10.1038/sj.bdj.2018.861 
10. Lopes MVO, Silva VM, Araujo TL. Methods for establishing the accuracy of clinical indicators in predicting nursing diagnoses. Int J Nurs Knowl. 2012;23(3):134-9. doi: https://doi.org//10.1111/j.2047-3095.2012.01213.x

11. Galindo Neto NM, Caetano JA, Barros LM, Silva TM, Vasconcelos EMR. First aid in schools: construction and validation of an educational booklet for teachers. Acta Paul Enferm. 2017;30(1):87-93. doi: https://doi. org/10.1590/1982-0194201700013

12. Polit D, Beck CT. The Content validity index: are you sure you know what's being reported? critique and recommendations. Res Nurs Health. 2006;29(5):489-97. doi: https://doi.org/10.1002/nur.20147

13. Portela NLC, Pedrosa A0, Silva NS, Ramos JS, Silva RS, Santos RTC. Occupational risks among employees of the mobile service of emergency care. ReonFacema. 2018 [cited 2020 Jul 07];4(2):1054-1061. Avaliable from: http://www.facema. edu.br/ojs/index.php/ReOnFacema/article/view/383/245

14. Van Doremalen N, BushmakerT, Morris DH, Holbrook MG, Gamble A, Williamson $B N$, et al. Aerosol and surface stability of SARS-CoV-2 as compared with SARSCoV-1. N Engl J Med. 2020;382:16. doi: https://doi.org/10.1101/2020.03.09. 20033217

15. World Health Organization $(\mathrm{CH})$. Infection prevention during transfer and transport of patients with suspected COVID-19 requiring hospital care. [Geneva]: WHO; 2020 [cited 2020 Jul 08]. Available from: https://apps.who. int/iris/bitstream/handle/10665/331917/COVID-19-infection-preventionduring-transfer-and-transport-eng.pdf?sequence $=1$ \&isAllowed $=y$

16. Peres D, Boléo-Tomé JP, Santos G. Respiratory and facial protection: current perspectives in the context of the COVID-19 pandemic. Acta Med Port. 2020;33(9):583-91. doi: https://doi.org/10.20344/amp.14108
17. Klompas $M$, Baker $M$, Rhee C. What is an aerosol-generating procedure? JAMA Surg. 2020. Epub 2020 Dec 15. doi: https://doi.org/10.1001/ jamasurg.2020.6643

18. Centers for Disease Control and prevention (US). Atlanta (GA): CDC; C2020 [cited 2020 Jul 08]. Interim guidance for Emergency Medical Services (EMS) systems and 911 Public Safety Answering Points (PSAPs) for COVID-19 in the United States; [about 6 screens]. Available from: https://www.cdc.gov/ coronavirus/2019-ncov/hcp/guidance-for-ems.html

19. Agência Nacional de Vigilância Sanitária (BR). Nota Técnica GVIMS/GGTES/ANVISA № 04/2020. Orientações para serviços de saúde: medidas de prevenção e controle que devem ser adotadas durante a assistência aos casos suspeitos ou confirmados de infecção pelo novo coronavírus (SARS-COV-2). Braślila: ANVISA; 2020 [cited 2020 Jul 08];1(5):1-92. Available from: https://www20.anvisa.gov.br/ segurancadopaciente/index.php/alertas/item/nota-tecnica?category_id=244

20. Cavicchiolo ME, Doglioni N, Ventola MA, Biban P, Baraldi E, Trevisanuto D. Neonatal emergency transport system during COVID-19 pandemic in the Veneto Region: proposal for standard operating procedures [correspondence]. Pediatr Res. 2020 [cited 2020 Jul 08]. Epub 2020 May 7. Available from: https:// www.nature.com/articles/s41390-020-0937-z

21. Frota OP, Ferreira AM, Rigotti MA, Andrade D, Borges NMA, Ferreira JMA. Effectiveness of clinical surface cleaning and disinfection: evaluation methods. Rev Bras Enferm. 2020;73(1):e20180623. doi: https://doi. org/10.1590/0034-7167-2018-0623

22. Dias V, Carneiro M, Vidal C, Corradi M, Brandão D, Cunha C, et al. Guidelines on diagnosis, treatment and isolation of patients with COVID-19. J Infect Control. 2020 [cited 2020 Dec 29];9(2):58-77. Available from: https://jic-abih.com.br/ index.php/jic/article/view/295/pdf_1 


\section{- Acknowledgments:}

To the Dean of Research and Innovation of the Instituto Federal de Educação, Science and Technology of Pernambuco (IFPE) for funding and promoting this study.

\section{- Authorship contribution:}

Ana Carla Silva Alexandre: Conceptualization, Formal analysis, Funding acquisition, Investigation, Methodology, Project administration, Resources Software, Supervision. Validation, Visualization, Writing-original draft, Writingreview \& editing. Nelson Miguel Galindo Neto: Conceptualization, Data curation, Formal analysis, Investigation, Methodology, Project administration, Resources Software, Supervision, Validation, Visualization, Writing-review \& editing. Maria Aparecida de Souza Silva: Conceptualization, Data curation, Formal analysis, Investigation, Methodology, Resources Software, Supervision, Validation, Visualization, Writing-original draft, Writingreview \& editing.

Dária Catarina Silva Santos: Conceptualization, Data curation, Formal analysis, Investigation, Methodology, Supervision, Validation, Visualization, Writing-original draft.

Josicleide Montenegro da Silva Guedes Alcoforado: Conceptualization, Supervision, Validation, Visualization, Writing-review \& editing. Daniela Bezerra de Melo: Conceptualization, Supervision, Validation, Visualization, Writing-review \& editing.

\section{- Corresponding author:}

Ana Carla Silva Alexandre

Email: ana.alexandre@pesqueira.ifpe.edu.br

\section{Associate editor:}

Dagmar Elaine Kaiser

Editor-in-chief:

Approved: 01.27.2021
Maria da Graça Oliveira Crossetti 